\title{
Risk Management Issues of Village Fund Management in Kedung Pengawas Village
}

\author{
Mochamad Muslih ${ }^{1}$, Haryono Umar ${ }^{2}$ \\ ISTIE Tri Bhakti, Indonesia.Email: mochamadmuslih@stietribhakti.ac.id \\ 2Perbanas Institute, Indonesia. Email: Flamboyan24@gmail.com
}

\begin{abstract}
The purpose of this study was to study the application of risk management in the management of village funds in Kedung Pengawas village, Babelan, West Java, Indonesia. The research method is a qualitative method with a case study of the application of risk management in Kedung Pengawas Village. The results showed that the Kedung Pengawas Bekasi Village Office Management has not implemented a formal integrated risk management, but there has been risk-conscious behavior so that certain crucial targets have been anticipated and steps will be taken in the event of obstacles so that performance targets can be achieved.
\end{abstract}

Keywords: Village fund management, risk management, performance

\section{INTRODUCTION}

With the existence of village funds, the benefits have been widely felt by various parties. The results that have been achieved from the use of village funds are the fulfillment of basic needs, village facilities and infrastructure, development of village local economic potential, development of natural resources and sustainable environment, community empowerment, implementation of village governance, and community development. The benefits of having village funds have been felt by various parties at various levels in society. However, there are also many problems related to village funds. The fundamental problem that exists in the management of village funds is that villages do not have adequate human resources.

Kedung Pengawas Village is one of the villages in Babelan District, Bekasi, West Java, Indonesia. Most of the income in Kedung Pengawas village is from agricultural products. Its vision is the realization of a society that is independent, democratic, human resources that are trustworthy, reliable and superior in all fields in the era of globalization.

The vision and mission of the Kedung Pengawas Village Office is a far-reaching perspective for the people of Kedung Pengawas Village to be what will become and what their hopes will be about Kedung Pengawas Village.
Kedung Pengawas Village, which is located in Babelan District, Bekasi Regency, also receives village funds. The village funds he receives are primarily used to finance the provision of rural infrastructure such as roads and school buildings.

There are many risks associated with managing these village funds. Mistakes and irregularities in management can occur at any time at various stages of management. Because it is necessary to take steps to minimize the risk to the management of village funds. By identifying risks in advance and thinking about follow-up steps, at least the risks that will occur have been thought out in advance and the steps for handling them. Dafikpaku (2011) concluded based on the results of his research on risk management that those who fail to plan, plan to fail. So the risk must be anticipated in advance, and the steps that will be taken against the identified risks should be considered. The application of risk management can improve the performance of Kedung Pengawas Village in achieving its goals of welfare for the people of Kedung Pengawas Village.

Research on the benefits of risk management shows the benefits of risk management for improving entity performance. The concept of risk management was first issued by the Committee of Sponsoring Organizations (COSO, 2004). COSO states that the objective of risk management is to provide reasonable assurance regarding the achievement of the entity's goals, including the objectives of managing village funds. Callahan and Soileau (2017) concluded that 
there is a relationship between the maturity of the risk management process and the company's operating performance.

Thus risk management must be applied in the management of village funds. The application of risk management can reduce the obstacles to achieving village fund management objectives. Various problems can occur in the management of village funds. Predicting and managing risks that may occur in the future can minimize obstacles to achieving village fund management objectives. The question in this research is whether the village of Kedung Pengawas has implemented risk management in managing village funds.

\section{LITERATURE REVIEW}

\subsection{Village Fund Management}

With the issuance of law number 6 of 2014 concerning villages, villages received a special allocation from district funds. The purpose of allocating village funds is to focus more on village development. The objectives of village management according to law number 6 of 2014 include encouraging initiatives, movements and participation of village communities for the development of village potential and assets for common welfare and advancing the economy of rural communities and overcoming gaps in national development. Article 12 of the Republic of Indonesia Government Regulation Number 60 of 2014 above states that the amount of village funds is different for each village.

\subsection{Risk Management}

Risk management is an integrated risk management application in planning and executing company goals and objectives. With the discovery and issuance of Enterprise Risk Management (ERM) by COSO, the objectives in strategic planning were identified as risks that might hinder the achievement of the company's goals and objectives. After the risks are identified, a risk analysis and risk determination is carried out. With the stipulation of risks, guarantees for the achievement of these targets become more reasonable and steps can be taken to achieve them.

The magnitude of these risks must be determined from the beginning before annual planning is carried out. Regarding the company's goals, Mios, Kozula, and Pecina (2015) state that the goal of risk management is to increase the likelihood that an organization will be able to achieve its goals. However there has been a view to approach risk management in an integrated manner. D 'Arc (2001), for example, concluded from his research that a general approach to risk management would be preferred over an individual approach and an integrated approach would be preferred over a separatist approach.

\section{RESEARCH METHODS}

This study uses a qualitative research method with case study. The case studied is the application of risk management. This method will be used to evaluate the application of risk management in the management of village funds, and to suggest a suitable risk management application in the village of Kedung Pengawas, Babelan, Bekasi, West Java. The research location is the Kedung Pengawas Village Office, Babelan District, Bekasi, West Java. The research data used are primary data and secondary data. Sources of research data are informants, field observations, document observations, and websites.

\section{RESULTS AND DISCUSSION}

Based on the data that has been collected together, the research results will be presented.

\subsection{Research Result}

The initial question in this study was whether the village of Kedung Pengawas had implemented risk management in managing village funds. And if risk management has been applied in the management of village funds, how should it be applied. This question departs from the policy of the Central Government and the opinion of the Committee On Sponsoring Organizations of The Treadway Commission (2004) to implement risk management in managing village funds. Data were collected from 7 (seven) informants at the Kedung Pengawas Village Office and the Bekasi Kedung Pengawas Village community. The triangulation process was carried out by crosschecking the answers between the six informants and looking at several related documents.

The results of interviews with 7 (seven) informants showed relatively the same results, namely that there was no formal integrated risk management application in the village of Kedung Pengawas. But things that might happen to a certain target or activity, especially in the financial sector, must always be calculated upfront. 


\subsection{Discussion}

The results showed that in Kedung Pengawas Village, Babelan District, Bekasi District, risk management had not been implemented in an integrated and structured manner. This is because there has been no training on knowledge of risk management for the personnel of the Kedung Pengawas Village so that the management of the Kedung Pengawas Village Office does not yet understand what is meant by risk management.

There is a risk-taking behavior in several Kedung Pengawas Village activities, but the implementation is not integrated and there is no system. The risks identified only in the main activity, by the head of the relevant section, but not planned in writing through a systemic analysis and evaluation process. The implementation of risk management itself is not reported in a written and hierarchical manner.

Actually, the application of risk management in West Java Province has been regulated in the Decree of the Governor of West Java Number 903 / Kep.1541-Keu / 2015 concerning the Application of Risk Management in West Java Province. In the preamble to the Decree of the Governor of West Java, it is stated that in the context of implementing the management of state finances and assets within the Regional Government of West Java Province, it is necessary to apply risk management in supporting the achievement of organizational tasks and functions in the Regional Apparatus within the Regional Government of West Java Province effectively and efficiently. .

The implementation of risk management must be reported at various levels in the organization, so that follow-up steps can be taken on certain conditions. This risk management report does not yet exist in Kedung Pengawas Village.

In Presidential Regulation of the Republic of Indonesia number 81 of 2010 dated 21 December 2010 concerning the Grand Design of Bureaucratic Reform 2010-2025, the Government has established the 2010-2025 Bureaucratic Reform Grand Design.

In order to achieve the aforementioned goals, one of the targets targeted to be achieved by the Government in 2004-2009 is good governance. Risk management is one of the parameters of good governance. So the implementation of risk management has been the target of the Indonesian Government since 2009.

In the regulations below, namely the Bekasi Regent's regulation Number 26 of 2020 concerning the Application of Risk Management in the Bekasi District Government, the obligation to apply risk management has also been regulated.
The Kedung Pengawas Village Office has not felt urgent to implement formal risk management, especially in an integrated manner for all village supervisors, at the village entity level and at the village activity level. Risk assessment as required in Government Regulation No. 60/2008 is part of the overall risk management concept.

When described schematically, the risk awareness implementation stages can be described as shown on the following Figure 1:

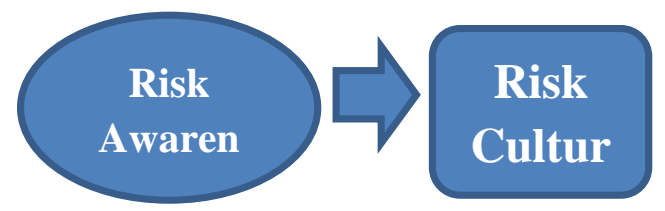

Figure 1. Risk Management Implementation Stages

At the RA stage, awareness of the risk exists, but has not been documented. At the RC stage, awareness of the existence of risks to the main goals of the organization already exists, and this awareness is documented in the organizational culture guidelines as a risk culture. At the ORM (Organization Risk Management) stage, all segments and stages of organizational risk management have been documented and their implementation monitored.

\section{CONCLUSION AND SUGGESTION}

Based on the research that has been done above, the results of these studies are as follows.

\subsection{Conclusion}

The initial objective of this study was to study whether the village of Kedung Pengawas, Babelan District, Bekasi, West Java, Indonesia, has implemented risk management in managing village funds. The results showed that the village of Kedung Pengawas had not formally applied risk management. The next question is how the management of Kedung Pengawas Kecamatan Babelan Bekasi manages the risks for all village fund management activities. The results showed that the management of Kedung Pengawas Village had actually anticipated all the risks that would occur and thought about the steps that would be taken if an obstacle occurred. 


\subsection{Suggestion}

Based on the results of the above research, the Kedung Pengawas Village Management suggested the following:

1. Conduct risk management dissemination activities for all employees of the Kedung Pengawas Village Office.

2. Create a Risk Management Guide for the Kedung Pengawas Village Office according to the needs of the Kedung Pengawas Village.

3. Internalizing the Risk Management Guidelines (PMR) of the Kedung Pengawas Village Office to all employees of the Kedung Pengawas Village Office and the Village Consultative Body (BPD).

4. Integrate risk management with all activities of Desa Kedung Pengawas.

\section{REFERENCES}

1. Nurwulandari, A., Hasanudin, H., \& Budi, A. J. S. (2021). Analysis Of The Influence Of Interest Rate, Exchange Value, World Gold Prices, Dow Jones Index, Aex Index, Dax Index, And Shanghai Index On Lq45 Index In Indonesia Stock Exchange 2012-2018. JABE (Journal of Applied Business and Economic), 7(2), 135-147.

2. Bupati Bekasi.(2020). Peraturan Bupati Bekasi Nomor 26 Tahun 2020 Tentang Penerapan Manajemen Resiko Pada Pemerintah Daerah Kabupaten Bekasi. Berita Daerah Kabupaten Bekasi Tahun 2020.

3. Bupati Bekasi. Peraturan Bupati Bekasi Nomor 35 Tahun 2011 tentang Penyelenggaraan Sistem Pengendalian Intern Pemerintah di Lingkungan Pemerintah Kabupaten Bekasi. Berita Daerah Kabupaten Bekasi Tahun 2011 Nomor 35.

4. Callahan, Carrolyn. Soileau, Jarod. (2017). Does Enterprise risk management enhance operating performance? Elsevier.

5. Committee of Sponsoring Organizations of Treadway Commission. (2004). Enterprise Risk Management - Integrated Framework: Executive
Summary. Committee of Sponsoring Organizations of Treadway Commission, Jersey City, NJ.

6. D'Arc, Stephen P. (2001). Enterprise Risk Management. Journal of Risk Management of Korea Volume 12.

7. Dafikpaku, Ezeosa. (2011). The Strategic Implications of Enterprise Risk Management: A Framework. Enterprise Risk Management Symposium Society of Actuaries.

8. Gubernur Jawa Barat. (2015). Keputusan Gubernur Jawa Barat Nomor 903/Kep.1541Keu/2015 tentang Penerapan Manajemen Resiko di Daerah Provinsi Jawa Barat. Pemerintah Provinsi Jawa Barat.

9. Kementerian Desa, Pembangunan Daerah Tertinggal, dan Transmigrasi Republik Indonesia. (2020). Peraturan Menteri Desa, Pembangunan Daerah Tertinggal, Dan Transmigrasi Republik Indonesia Nomor 9 Tahun 2020 Tentang Penerapan Manajemen Resiko Di Lingkungan Kementerian Desa, Pembangunan Daerah Tertinggal, dan Transmigrasi.

10. Melati, M., \& Nurwulandari, A. (2019). Analisis Reaksi Pasar terhadap Stock Split pada Perusahaan Bertumbuh dan Tidak Bertumbuh. Oikonomia: Jurnal Manajemen, 13(2).

11. Noer, M., Saribanon, N., \& Nurwulandari, A. (2017). Business Model Analysis of Natural Production Forest with Sustainable Forest Management Approach.

12. Presiden Republik Indonesia. (2010). Peraturan Presiden Republik Indonesia Nomor 81 Tahun 2010 tentang Grand Design Reformasi Birokrasi 2010-2025. Deputi Sekretaris Kabinet Bidang Hukum.

13. Walikota Bekasi. (2017). Peraturan Walikota Bekasi Nomor 12 Tahun 2017 Tentang Penerapan Manajemen Resiko Di Lingkungan Pemerintah Kota Bekasi. Berita Daerah Kota Bekasi Tahun 2016 Nomor 12 Seri E. 